\title{
Physico-chemical and Sensory Characteristics of Semi-dried Sausages Containing Different Levels of Kimchi Powder
}

\author{
Mi-Ai Lee, Doo-Jeong Han, Ji-Hun Choi, Yun-Sang Choi, Hack-Youn Kim, \\ Kwang-Il Ahn, Jong-Youn Jeong ${ }^{1}$, Chi-Ho Lee, and Cheon-Jei Kim* \\ Department of Food science and Biotechnology of Animal Resources, Konkuk University, Seoul 143-701, Korea \\ ${ }^{I}$ Department of Animal Science, University of Wisconsin-Madison, Muscle Biology and Meat Science Building, \\ 1805 Linden Drive West, Madison WI 53706, United States
}

\begin{abstract}
Effects of the addition of kimchi powder on the physico-chemical and sensory properties of semi-dried sausages were investigated at the following kimchi powder concentrations: control (0\%), T1 (1\%), T2 (2\%), and T3 (3\%). pH of the semidried sausages containing kimchi powder decreased with the addition of kimchi $(p<0.05)$. Also, the addition of kimchi powder to the sausages significantly decreased the CIE $\mathrm{L}^{*}$ and increased the CIE $\mathrm{a}^{*}$ and CIE $\mathrm{b}^{*}$ values $(p<0.05)$. The T3 treatment resulted a higher mositure lose than other treatments. TBARS values of the T2 and T3 groups were significantly lower $(p<0.05)$ than that of the control, while T3 had the highest VBN value among treatments at the end of the storage period. Addition of kimchi powder to semi-dried sausages improved the overall sensory properties of the sausages, and increased the softness and tenderness. These results suggest that addition of $2 \%$ kimchi powder to semi-dried sausage is helpful to improve the quality of sausages.
\end{abstract}

Key words : semi-dried sausage, kimchi, dietary fiber, sensory properties, quality characteristics

\section{Introduction}

Functional foods can be defined as foods providing health benefits above basic nutrition (Bech-Larsen and Grunert, 2003). Functional attributes of many traditional foods are being discovered, while new food products are being developed with beneficial components (Eim et al., 2008). Producers and processors have responded to consumer demand for foods perceived by many to be more healthy and wholesome than conventionally produced food products (Sebranek and Bacus, 2007). Meat and meat products may also be considered as functional foods to the extent that they contain numerous compounds thought to be functional. The idea of using foods for health purposes rather than for nutrition opens up a whole new field for the meat industry (Calvo et al., 2007; Jimenez-Colmenro et al., 2001). In addition to traditional meat products, the meat industry can explore various new pos-

*Corresponding author : Cheon Jei Kim, Department of Food science and Biotechnology of Animal Resources, Konkuk University, 1 Hawayang-dong, Kwangjin-gu, Seoul 143-701, Korea, Tel: +82-2-450-3684, Fax: +82-2-444-6695, E-mail: kimcj@konkuk.ac.kr sibilities, including the control of the composition of raw and processed materials via the reformulation of fatty acid profiles or the inclusion of antioxidants, dietary fiber, probiotics, etc. (Kovacs et al., 2007; Mendoza et al., 2001).

Over last few decades, there have been the expansion of knowledge of the influence of diet on health and wellbeing. The most popular kimchi is baechu kimchi, which is made with Korean baechu cabbage (Cheigh and Park, 1994). Fermented kimchi usually contains high levels of lactic acid bacteria, organic acids, and other nutrients such as vitamins, minerals, dietary fiber, and functional components form during fermentation (Cheigh and Park, 1994; Park, 1995). Thus, kimchi might be called a lactic acid bacteria fermented food as well as a functional food. Kimchi is known to help increase appetite, reduce constipation, maintain proper intestinal flora, and has been reported to have antimutagenic effects, anticarcinogenic effects, anti-aging effects and other health benefits (Hwang and Song, 2000; Kim et al., 1998; Park et al., 1995). The major raw materials of kimchi are vegetable and spices including ginger, garlic, green onion, and paprika which contain antioxidants compounds such as ascorbic acid, carotenoids, flavonoids, phenolic compounds, and tocopherols (Cheigh and Park, 1994; Park, 1995). 
Kimchi, is suitable for meat products, contains $32.50 \%$ of dietary fiber on a dry weight basis (Lee et al., 2008b). Various types of kimchi powder have been studied alone or in combination with other ingredients for the formulation of reduced fat meat products (Lee et al., 2008a).

Dietary fiber is desirable not only for their nutritional properties, but also its functional and technological properties in reducing formulation cost, substituting fat and enhancing texture (Akoh, 1998; Fernandez-Gin et al., 2005; Jimenez-Colmenero, 1996). Dietary fiber retains water, increases cooking yields and has a neutral flavor, appropriate for meat products, and has previously been added to meat products to increase the cooking yield because of its water and fat binding properties (Cofrades et al., 2000; thebaudin et al., 1997). The utilization of kimchi powder for meat processing and its potential use as an additive are not well understood.

The aim of this study was to evaluate the influence of kimchi powder levels on the color attributes of semi-dried sausage, and to determine the physico-chemical, sensory properties, and storage stability of meat products with different kimchi powder levels.

\section{Materials and methods}

\section{Kimchi powder preparation}

Commercial Baechu (Korean white cabbage) kimchi, the style of central districts in Korea, was purchased from a local market (Chongga kimchi, Daesang FNF, Seoul, Korea). It was prepared as follows (\%); Chinese cabbages, cut into half heads, were dipped in $15 \%(\mathrm{w} / \mathrm{v})$ brine for $4 \mathrm{~h}$. The pieces of cabbage were washed with tap water, drained and then mixed with spices and additives. The recipe of ingredients and additives were $68.1 \%$ salted Chinese cabbage, $16 \%$ sliced radish, $6 \%$ green onion, $2 \%$ onion, $1.6 \%$ scallion, $1.2 \%$ fermented shrimp, $1.2 \%$ fermented anchovy sauce, $2 \%$ red pepper powder, $1.2 \%$ chopped garlic, and $0.6 \%$ chopped ginger. At the beginning of fermentation, the averaged $\mathrm{pH}$ values of kimchi packaged with PE/Nylon film bags with sealing were $\mathrm{pH}$ 5.4, and them gradually decreased to $\mathrm{pH} 4.3$ until approached the optimal sensory condition (Hong and Park, 1999; Park and Lee, 1995) in a period of 15 days at $4 \pm 1^{\circ} \mathrm{C}$. Fermented kimchi was blended with a cutter (C4 VV, Sirman, Marsango, Italy) and then the blended kimchi was packaged in portions of approximately $300 \mathrm{~g}$ per in PE/Nylon film bags and pressed flat. The vacuumpackaged kimchi was immediately frozen at $-20 \pm 1^{\circ} \mathrm{C}$ until use. Kimchi was dried in a hot air dryer (Enex-Co-600,
Enex, Yongin, Korea) at $60 \pm 1^{\circ} \mathrm{C}$. For $12 \mathrm{~h}$ until kimchi contained $<15 \%$ final moisture, kimchi was finely ground to a particle size of $<0.5 \mathrm{~mm}$ ( $35 \mathrm{mesh}$ ) followed by storage in a deep freezer $\left(-70^{\circ} \mathrm{C}\right)$ until further use. The chemical compositions of the kimchi powder, determined in triplicates according to the AOAC (1995) method were: $8.02 \mathrm{~g} / 100 \mathrm{~g}$ moisture, $13.62 \mathrm{~g} / 100 \mathrm{~g}$ protein, $5.88 \mathrm{~g} / 100$ $\mathrm{g}$ fat, $18.05 \mathrm{~g} / 100 \mathrm{~g}$, and $32.50 \mathrm{~g} / 100 \mathrm{~g}$.

\section{Processing of semi-dried sausage}

Biceps femoris muscle, Semitendinosus muscle, Semimembranosus muscle from fresh pork (castrated boars; LandracexYorkshirexDuroc; approximately $110 \mathrm{~kg}$ ), weighing 6.8-7.2 kg each, were purchased from a local processor at $48 \mathrm{~h}$ postmortem. Pork back fat was also collected. All subcutaneous and intramuscular fat and visible connective tissues were removed from the fresh ham muscles. Lean meat and back fat were ground through an 8 mm plate. Semi-dried sausages were manufactured based on the following formulation; $90 \%$ lean pork meat, $10 \%$ pork back fat, $1.5 \%$ sodium chloride, $0.15 \%$ phosphate, and $0.1 \%$ monosodium L-glutamate and three batches contained different amounts of kimchi powder in the final meat mixture: $1 \%$ (T1), 2\% (T2), and 3\% (T3). The fourth batch was manufactured without kimchi powder as a control. The addition of sodium chloride controlled as kimchi powder level because kimchi powder had $10 \%$ salt content, therefore sodium chloride added $1.5 \%$ (control), $1.4 \%$ (T1), $1.3 \%$ (T2), and $1.2 \%$ (T3), respectively. Since kimchi contains $10 \%$ salt, the amount of sodium chloride added was adjusted for each formulation so that the final concentration was $1.5 \%$.

The manufacturing process of the semi-dried sausages was as follows. Four batches ( $2 \mathrm{~kg}$ each) were prepared for each formulation. For each batch of sausage, the meat and phosphate were mixed by hand for $3 \mathrm{~min}$ and then cured at $4{ }^{\circ} \mathrm{C}$ for $12 \mathrm{~h}$ and then, the cured pork meats were the added to kimchi powder, and other ingredients and were emulsified using a silent cutter (Nr-963009, Scharfen, Witten, Germany) for $3 \mathrm{~min}$. After emulsification, the meat batter was stuffed into collagen casings (\#240, NIPPI Inc., Tokyo, Japan; approximate $25 \mathrm{~mm}$ diameter) using a stuffer (IS-8, Sirman, Marsango, Italy), dried at $55^{\circ} \mathrm{C}$ for $30 \mathrm{~min}$ and smoked at $65^{\circ} \mathrm{C}$ for $60 \mathrm{~min}$ followed by heating at $80^{\circ} \mathrm{C}$ for $60 \mathrm{~min}$. After cooling with cold water, the semi-dried sausages were anaerobically packed in PE/nylon film bags, stored at $4^{\circ} \mathrm{C}$ for 6 wk and analyzed for $\mathrm{pH}$, instrumental color, compositional properties, texture profile analysis, sensory evalua- 
tion, and thiobarbituric acid reactive substances (TBARS), volatile basic nitrogen (VBN). All parameters and sensory evaluations were assessed on day 0 except for TBARS and VBN values which were analyzed throughout storage. All analyses were carried out in triplicate for each sausage formulation.

\section{Analytical measurements}

Proximate composition and water activity

Compositional properties were determined by AOAC (AOAC, 1995) procedures. Moisture content was determined by weight loss of drying a $3 \mathrm{~g}$ sample at $105{ }^{\circ} \mathrm{C}$ for $12 \mathrm{~h}$ in a vacuum oven. The fat content was determined by weight loss of $1 \mathrm{~g}$ sample after extraction for $24 \mathrm{~h}$ with petroleum ether in a Sohxlet apparatus. The protein content was determined by the Kjeldahl method using $1.2 \mathrm{~g}$ sample with an automatic Kjeldahl nitrogen analyzer (Kjeltec ${ }^{\circledR} 2300$ Analyzer Unit, Foss Tecator AB, Höganas, Sweden). The ash content was determined by weight loss of $2 \mathrm{~g}$ sample after heating at $550^{\circ} \mathrm{C}$ for $5 \mathrm{~h}$. Samples used to measure water activity $\left(a_{w}\right)$ were minced into pieces approximately $1 \mathrm{~mm} \times 1 \mathrm{~mm} \times 1 \mathrm{~mm}$ in size. The water activity of each sample was determined in duplicate with a hygrometer (BT-RS1, Rotronic, Bassersdorf, Switzerland).

\section{Processing yield}

The meat batters were stuffed into casings and weighted before cooking followed by drying $\left(55^{\circ} \mathrm{C}\right.$ for $\left.30 \mathrm{~min}\right)$, smoking $\left(65^{\circ} \mathrm{C}\right.$ for $\left.60 \mathrm{~min}\right)$, heating $\left(80^{\circ} \mathrm{C}\right.$ for $\left.60 \mathrm{~min}\right)$ and cooling with cold water. After cooling for $1 \mathrm{~h}$, semidried sausages were weighed and the percentage processing yield was calculated from the weights.

\section{Color measurements}

Sausages were cut into $3 \mathrm{~mm}$ thick slices, and color was measured immediately after cutting the samples to prevent color degradation due to exposure to light and oxygen. Color measurements were taken with a colorimeter (Chroma meter CR-210, Minolta, Japan; illuminate C, calibrated with white standard plate $L^{*}=97.83, a^{*}=$ $-0.43, b^{*}=+1.98$ ), using an $8 \mathrm{~mm}$ diameter measuring area and a $50 \mathrm{~mm}$ diameter illumination area. Color values (CIE L, a, and b) were measured on internal samples and were done in triplicate for each sample. Hue angle $\left(\mathrm{h}^{\circ}\right)$ and chroma (C) were calculated by the following formula: $\left(\mathrm{h}^{\circ} ; \operatorname{Tan}^{-1}(\mathrm{~b} / \mathrm{a}),\left(\mathrm{C} ;\left(\mathrm{a}^{2}+\mathrm{b}^{2}\right)^{1 / 2}\right)\right.$, Hug angle $(0=\mathrm{red}$, $90=$ yellow, 180=green). Hue angle and chroma were esti- mated as described by Hunt et al. (1991). Three measurements were done for three different spots on the surface of each sausage these values were averaged.

$\mathrm{pH}$

Five $\mathrm{g}$ of samples were homogenized with $20 \mathrm{~mL}$ distilled water, and $\mathrm{pH}$ values of the homogenates was determined with a pH meter (Model 340, Mettler-Toledo GmbH, Schwerzenbach, Switzerland).

Thiobarbituric acid reacting substance (TBARS) and volatile basic nitrogen (VBN)

TBARS values were expressed as mg malonaldehyde/ $\mathrm{kg}$ samples and estimated colorimetrically using 2-thiobarbituric acid (Tarladgis et al., 1960). The absorbance was measured at $538 \mathrm{~nm}$ with UV spectrophotometer (Brochrom, Libra S22, England). The K value was calculated as described by Tarladgis et al (1960) using 1,1,3,3tetraethoxypropane (Sigma) as the standard and the TBARS values were calculated by multiplying the absorbance values by the $\mathrm{K}$ value. Volatile basic nitrogen ( $\mathrm{mg} / \%)$ test was performed to determine the extent of protein deterioration during refrigerated storage. VBN was measured by the modified micro diffusion assay according to the method of Pearson (1968).

$$
\operatorname{VBN}(\mathrm{mg} \%)=\frac{(a-b) \times(f \times 0.02 \times N \times 14.007 \times 100 \times 100)}{S}
$$

Where, $\mathrm{a}=$ titer for sample, $\mathrm{b}=$ titer for blank, $f=$ factor of reagent, $\mathrm{N}=$ normality, $\mathrm{S}=$ sample weight $(\mathrm{g})$.

Texture profile analysis (TPA)

Texture measurements in the form of texture profile analysis were performed at room temperature with a texture analyzer (TA-XT2i, Stable Micro System Ltd., Surrey, England). Samples were cooked as previously described. After cooking, cooked sausages were immediately at room temperature $\left(25 \pm 1^{\circ} \mathrm{C}\right)$ for $1 \mathrm{hr}$ to determine textural properties. Semi-dried sausage samples (size: diameter of $16 \mathrm{~mm}$, height $25 \mathrm{~mm}$ ) were taken from the central portion of each sausage. The conditions of texture analysis were as follows: $\phi 25 \mathrm{~mm}$ spherical probe, pre-test speed; $2.0 \mathrm{~mm} / \mathrm{s}$, post-test speed; $5.0 \mathrm{~mm} / \mathrm{s}$, distance; $8 \mathrm{~mm}$, force; $5 \mathrm{~g}$, The calculation of TPA values was obtained by graphing a curve using force and time plots. Values for hardness $(\mathrm{N})$, springiness, cohesiveness, gumminess $(\mathrm{N})$, and chewiness $(\mathrm{N})$ were determined as described (Bourne, 1978). All determinations were performed in each of three replicates. 
Sensory evaluations

Sensory evaluations were performed in triplicate for each sausage using trained panelists. Recruitment, selection, and training of panelists were performed according to sensory evaluation procedures (Meilgaard et al., 1999), and 10 panelists were chosen from 15 potential panelists using basic taste identification tests. The panelists were trained with commercial sausage product for $2 \mathrm{wk}$ (three 30 min sessions per wk) to familiarize them with the characteristics of the product to be evaluated. During each evaluation, the panelists were situated in private booths under incandescent light with an intensity of approximately 350 lux. Approximately $10 \mathrm{~mm}$ cube were cut from the center of sausages and served at a temperature of approximately $60 \pm 1^{\circ} \mathrm{C}$ to each panelist. Panelists were instructed to cleanse their palates between samples using warm water $\left(30 \pm 1^{\circ} \mathrm{C}\right)$. The color, flavor, kimchi taste, and overall acceptability ( $1=$ extremely undesirable and $10=$ extremely desirable), tenderness ( $1=$ extremely tough and $10=$ extremely tender), juiciness (1=extremely dry and $10=$ extremely juicy) of the samples were evaluated using a 10-point horizontal scale.

\section{Statistical analysis}

The experiment was replicated three times where three samples from each batch were analyzed. An analyses of variance were performed on all the variables measured using the General Linear Model (GLM) procedure of the SAS statistical package (SAS, 1999). The Duncan's multiple range test with $\alpha=0.05 \%$.was used to determine the differences between treatment means.

\section{Results and Discussion}

\section{Proximate composition}

Table 1 shows the compositional properties of the semidried sausages with or without kimchi powder. When kimchi powder concentration increased, moisture and ash contents were increased while protein content decreased. There are no significant difference in fat content and water activity $\left(\mathrm{a}_{\mathrm{w}}\right)$. Moisture concentrations of sausages were increased when kimchi powder was added $(p<0.05)$. The increase in the concentration of dietary fiber increases the moisture content of the sausages, which could be due to the high water-retention of kimchi powder. The dietary fiber content of dried kimchi was about $32.50 \%$ (Lee et al., 2008b), and its water absorption capacity was $326 \%$ in cold condition and $409 \%$ in hot condition. Steenblock et al. (2001) reported that addition of oat fiber increased moisture content of frankfurters. The ash content increased when kimchi powder was added, depending on the kimchi powder concentration. Ayo et al. (2008) reported that the addition of walnut significantly raises the ash level. The levels of protein were decreased $(p<0.05)$, respectively as kimchi powder concentration increased, but no significant differences $(p<0.05)$ were observed in fat content among the test and control formulations. The water activity $\left(\mathrm{a}_{\mathrm{w}}\right)$ was not affected by the addition of kimchi powder and according to Eim et al. (2008), the water activity decreases in sausages enriched with carrot fiber, whereas the water content increases. Garcia et al. (2002) obtained similar results in dry sausages which water activity $\left(\mathrm{a}_{\mathrm{w}}\right)$ was not affected by dietary fiber contents added.

Table 1. pH, processing yield, proximate compositions, and water activity of semi-dried sausages with various levels of kimchi powder ${ }^{1)}$

\begin{tabular}{|c|c|c|c|c|}
\hline \multirow{2}{*}{ Parameters } & \multicolumn{4}{|c|}{ "Treatments ${ }^{2)}$} \\
\hline & Control & $\mathrm{T} 1$ & $\mathrm{~T} 2$ & $\mathrm{~T} 3$ \\
\hline $\mathrm{pH}$ & $6.05 \pm 0.01^{\mathrm{a}}$ & $6.04 \pm 0.01^{\mathrm{a}}$ & $5.98 \pm 0.01^{b}$ & $5.91 \pm 0.02^{\mathrm{c}}$ \\
\hline Processing yield & $84.37 \pm 0.64^{c}$ & $85.20 \pm 0.81^{\mathrm{b}}$ & $87.14 \pm 0.52^{a}$ & $86.64 \pm 0.94^{\mathrm{a}}$ \\
\hline Moisture (\%) & $57.60 \pm 0.85^{\mathrm{b}}$ & $58.17 \pm 0.81^{\mathrm{ab}}$ & $59.13 \pm 0.65^{\mathrm{a}}$ & $59.30 \pm 0.72^{\mathrm{a}}$ \\
\hline Protein $(\%)$ & $25.71 \pm 1.01^{\mathrm{a}}$ & $24.64 \pm 0.17^{\mathrm{b}}$ & $23.66 \pm 0.19^{c}$ & $23.22 \pm 0.63^{c}$ \\
\hline Fat $(\%)$ & $12.57 \pm 0.17$ & $12.67 \pm 0.14$ & $12.63 \pm 0.18$ & $12.62 \pm 0.35$ \\
\hline $\operatorname{Ash}(\%)$ & $3.01 \pm 0.08^{\mathrm{b}}$ & $3.27 \pm 0.14^{\mathrm{a}}$ & $3.31 \pm 0.19^{\mathrm{a}}$ & $3.40 \pm 0.03^{\mathrm{a}}$ \\
\hline Water activity $\left(\mathrm{a}_{\mathrm{w}}\right)$ & $0.92 \pm 0.01$ & $0.93 \pm 0.01$ & $0.94 \pm 0.01$ & $0.94 \pm 0.01$ \\
\hline
\end{tabular}

${ }^{1)}$ All values are mean \pm SD of the three replicates.

${ }^{\mathrm{a}-\mathrm{c}}$ Means sharing different letters in the same row are significantly different $(p<0.05)$.

${ }^{2)}$ Control, semi-dried sausage without kimchi powder; T1, semi-dried sausage with $1 \%$ hot air dried kimchi powder; T2, semi-dried sausage with $2 \%$ hot air dried kimchi powder; T3, semi-dried sausage with $3 \%$ hot air dried kimchi powder. 


\section{Processing yields of semi-dried sausages}

The processing yields of semi-dried sausages with kimchi powder are shown in Table 1. The semi-dried sausages formulated with kimchi powder had significantly higher processing yields than control $(p<0.05)$. The $2 \%$ and $3 \%$ of kimchi powder produced more processing yield, indicating that the addition of kimchi powder is useful for retaining product moisture during cooking. Similar results reported that Hughes et al. (1997) and Morin et al. (2004) showed that addition of dietary fiber increased cooking yield of meat products. Use of dietary fiber from different sources increased cooking yield because of their binding properties (Grigelmo-Miguel et al., 1999; Thebaudin, 1997). Therefore, dietary fiber from kimchi powder is useful in processing meat products because of its ability to enhance these properties in meat products (Lee et al., 2008a).

Shand (2000) also showed that addition of potato starch and waxy barley increased cooking yield of frankfurters. Cofrades et al. (2000) and Hughes et al. (1997) reported that higher expressible moisture values were found with increased added water and lower levels of soy fiber, carrageenan, or oat fiber, and Steenblock et al. (2001) earlier reported that oat fiber has the ability to retain moisture and prevent meats from drying out when cooked.

\section{pH value and color properties of semi-dried sau- sages}

The $\mathrm{pH}$ values of semi-dried sausages prepared with added kimchi powder are shown in Table 1 . The $\mathrm{pH}$ value of the control was not significantly different from $\mathrm{T} 1$, and the lowest $\mathrm{pH}$ value was seen in $\mathrm{T} 3$. The $\mathrm{pH}$ values of semi-dried sausages containing kimchi powder were affected by the low $\mathrm{pH}$ of kimchi powder because of the $\mathrm{pH}$ values of kimchi powder was significantly lower than raw meat, being $\mathrm{pH}$ 4.48. Deda et al. (2007) reported a decrease in the $\mathrm{pH}$ value of meat products containing tomato paste which had $\mathrm{pH}$ of 4.45 . The addition of soy fiber (Cofrades et al., 2000), and lemon albedo (AlesonCarbonell, 2003) also affected the $\mathrm{pH}$ values of meat products. However, Ayo et al. (2008) noted that there was no significant effect due to carrageenan and walnut addition on the $\mathrm{pH}$ of pork sausage formulations.

Table 2 shows the color parameters of the semi-dried sausages. Hue angle and chroma were obtained from the CIE L ${ }^{*}, a^{*}$, and $b^{*}$ coordinates for all supplemented samples. The addition of kimchi powder affected all color parameters of the final products $(p<0.05)$. The T3 had the lowest $(p<0.05)$ lightness $\left(\mathrm{CIE} \mathrm{L}{ }^{*}\right)$ and the highest $(p<$ 0.05 ) redness and yellowness values. The increases in CIE $a^{*}$ and $\mathrm{CIE} \mathrm{b}^{*}$ values in batches $\mathrm{T} 1, \mathrm{~T} 2$, and $\mathrm{T} 3$ were due to the kimchi powder color. The biggest difference between the control and the kimchi powder enriched batches was observed in the CIE $b^{*}$ parameter, where values for batches T1, T2, and T3 were almost two fold higher than the control. These variations could be due to the carotene content of kimchi, which varies depending on the use of red pepper. Capsaicin, $\beta$-carotene, cryptoxanthin, and in particular members of the carotenoid group, may increase CIE $a^{*}$ and CIE $b^{*}$ values in sausages containing kimchi. Also, the coordinate had the largest influence on hue angle and saturation index. All the samples had a hue angle index of between 23.57 and 44.51 indicating red and orange color $(p<0.05)$. Higher percentages of kimchi powder led to higher hue angles and chroma values compared to the control. Calvo et al. (2007) reported that the addition of dry tomato peel in dry sausages resulted in higher hue angles and saturation indexes indicative of the CIE $\mathrm{b}^{*}$ parameter. Eim et al. (2008) also reported that the addition of carrot dietary fiber in dry sausages led to higher color differences in comparision. Although color changes have been reported as being induced by the pres-

Table 2. Effect of color (CIE $\mathrm{L}^{*}, \mathrm{a}^{*}$, and $\left.\mathrm{b}^{*}\right)$ on semi-dried sausages formulated with various levels of kimchi powder ${ }^{1)}$

\begin{tabular}{lrrrr}
\hline \hline \multirow{2}{*}{ Parameters } & \multicolumn{3}{c}{ Treatments $^{2)}$} \\
\cline { 2 - 5 } & \multicolumn{1}{c}{ Control } & \multicolumn{1}{c}{$\mathrm{T} 1$} & 53 \\
\hline CIE L $^{*}$ & $56.95 \pm 0.48^{\mathrm{a}}$ & $56.47 \pm 0.38^{\mathrm{ab}}$ & $56.08 \pm 0.49^{\mathrm{b}}$ & $55.54 \pm 0.36^{\mathrm{c}}$ \\
$\mathrm{CIE} \mathrm{a}^{*}$ & $10.19 \pm 0.41^{\mathrm{c}}$ & $11.04 \pm 0.22^{\mathrm{b}}$ & $11.27 \pm 0.22^{\mathrm{b}}$ & $11.86 \pm 0.37^{\mathrm{a}}$ \\
$\mathrm{CIE} \mathrm{b}^{*}$ & $4.45 \pm 0.26^{\mathrm{d}}$ & $8.14 \pm 0.34^{\mathrm{c}}$ & $10.01 \pm 0.31^{\mathrm{b}}$ & $11.67 \pm 0.58^{\mathrm{a}}$ \\
${\text { Hue angle }\left(\mathrm{H}^{\circ}\right)}^{\text {Chroma }(\mathrm{C})}$ & $23.57 \pm 0.46^{\mathrm{d}}$ & $36.36 \pm 0.66^{\mathrm{c}}$ & $41.61 \pm 0.45^{\mathrm{b}}$ & $44.51 \pm 0.45^{\mathrm{a}}$ \\
\hline
\end{tabular}

${ }^{1)}$ All values are mean \pm SD of the three replicates.

${ }^{\mathrm{a}-\mathrm{d}}$ Means sharing different letters in the same row are significantly different $(p<0.05)$.

${ }^{2)}$ Control, semi-dried sausage without kimchi powder; T1, semi-dried sausage with $1 \%$ hot air dried kimchi powder; T2, semi-dried sausage with $2 \%$ hot air dried kimchi powder; T3, semi-dried sausage with 3\% hot air dried kimchi powder; Hue angle calculated as Tan ${ }^{-1}$ (b/a): $90^{\circ}=$ yellow $180^{\circ}=$ green and $0^{\circ}=$ red Chroma calculated as $\left(\mathrm{a}^{2}+\mathrm{b}^{2}\right)^{1 / 2}$. 
Table 3. Effect of textural properties of semi-dried sausages formulated with various levels of kimchi powder ${ }^{1)}$

\begin{tabular}{lcccc}
\hline \hline \multirow{2}{*}{ Parameters } & \multicolumn{3}{c}{ Treatments $^{2)}$} \\
\cline { 2 - 5 } & Control & T1 & T2 & T3 \\
\hline Hardness (N) & $10.54 \pm 0.66^{\mathrm{a}}$ & $10.22 \pm 0.89^{\mathrm{ab}}$ & $9.84 \pm 0.94^{\mathrm{b}}$ & $8.94 \pm 0.59^{\mathrm{c}}$ \\
Springiness & $0.95 \pm 0.03$ & $0.95 \pm 0.01$ & $0.95 \pm 0.04$ & $0.96 \pm 0.03$ \\
Cohesiveness & $0.54 \pm 0.05$ & $0.52 \pm 0.04$ & $0.51 \pm 0.04$ & $0.51 \pm 0.03$ \\
Gumminess (N) & $5.65 \pm 0.45^{\mathrm{a}}$ & $5.31 \pm 0.55^{\mathrm{ab}}$ & $5.02 \pm 0.51^{\mathrm{b}}$ & $4.58 \pm 0.40^{\mathrm{c}}$ \\
Chewiness (N) & $5.39 \pm 0.42^{\mathrm{a}}$ & $5.06 \pm 0.53^{\mathrm{ab}}$ & $4.79 \pm 0.54^{\mathrm{bc}}$ & $4.42 \pm 0.39^{\mathrm{c}}$ \\
\hline
\end{tabular}

${ }^{1)}$ All values are mean \pm SD of the three replicates.

${ }^{\mathrm{a}-\mathrm{c}}$ Means sharing different letters in the same row are significantly different $(p<0.05)$.

${ }^{2)}$ Control, semi-dried sausage without kimchi powder; T1, semi-dried sausage with $1 \%$ hot air dried kimchi powder; T2, semi-dried sausage with $2 \%$ hot air dried kimchi powder; T3. semi-dried sausage with 3\% hot air dried kimchi powder.

ence of fiber of various origins in various meat products (Cofrades et al., 2000; Grigelmo-Miguel et al., 1999; Claus and Hunt, 1991), in other case no effect was observed (Hughes et al., 1997).

\section{Textural properties of semi-dried sausages}

Textural profile analysis (TPA) measurements may determine the quality of the finished product and can contribute to the selection of the best functional ingredients (Herrero et al., 2007). The textural properties of the semidried sausages are shown in Table 3. The results indicate that kimchi powder content significantly affected the textural characteristics of semi-dried sausages. Comparing the control with test sausages, it can be seen that all hardness values were higher in control than in the sausages formulated with kimchi powder $(p<0.05)$. Significant differences were also observed for gumminess and chewiness and force of shearing. In all cases, the hardness decreased when kimchi powder was added. However, cohesiveness and springiness followed a different pattern, since increasing amounts of added kimchi powder resulted in no significant differences in cohesiveness and springiness $(p<0.05)$. Therefore hardness, gumminess, and chewiness decreased with increased concentrations of kimchi powder. The decrease of hardness, gumminess, and chewiness could be explained by the presence of fiber in the kimchi powder. Similar decreases in hardness, gumminess, and chewiness were reported for frankfurter sausages and gologna due to the addition of maltodextrin (Crehan et al., 2000), soy fiber (Cofrades et al., 2000), potato starch, and waxy barley (Shand, 2000). Also, Garcia et al. (2002) reported a marked decrease in hardness when wheat or oat fiber was added to dry fermented sausages, as a consequence of their insoluble dietary fiber content. Depending on the amount and type of fiber, controversial results have been reported on textural parameters. For example, both hardening and softening have been observed when fiber is added to various meat products. Thebaudin et al. (1997) reported that, because of water binding ability and swelling properties of insoluble fiber can positive influence food texture.

\section{Sensory properties of semi-dried sausages}

The results of sensory evaluation are presented in Table

Table 4. Sensory properties of semi-dried sausages as affected by addition of various kimchi powder level ${ }^{1)}$

\begin{tabular}{lcccc}
\hline \hline \multirow{2}{*}{ Parameters } & \multicolumn{3}{c}{ Treatments $^{2)}$} \\
\cline { 2 - 5 } & Control & T1 & T2 & T3 \\
\hline Color & $6.60 \pm 0.84^{\mathrm{c}}$ & $7.50 \pm 1.08^{\mathrm{b}}$ & $8.20 \pm 0.63^{\mathrm{b}}$ & $9.10 \pm 0.88^{\mathrm{a}}$ \\
Flavor & $7.00 \pm 0.67^{\mathrm{c}}$ & $7.90 \pm 0.57^{\mathrm{b}}$ & $8.90 \pm 0.88^{\mathrm{a}}$ & $8.80 \pm 0.79^{\mathrm{a}}$ \\
Tenderness & $5.20 \pm 0.79^{\mathrm{c}}$ & $5.80 \pm 0.79^{\mathrm{bc}}$ & $6.20 \pm 0.63^{\mathrm{b}}$ & $7.00 \pm 1.05^{\mathrm{a}}$ \\
Juiciness & $7.40 \pm 0.84^{\mathrm{c}}$ & $8.10 \pm 0.57^{\mathrm{bc}}$ & $8.20 \pm 0.79^{\mathrm{ab}}$ & $8.90 \pm 0.88^{\mathrm{a}}$ \\
Kimchi taste & $1.40 \pm 0.52^{\mathrm{c}}$ & $2.90 \pm 0.57^{\mathrm{b}}$ & $3.30 \pm 0.48^{\mathrm{b}}$ & $4.30 \pm 0.82^{\mathrm{a}}$ \\
Overall acceptability & $7.40 \pm 0.52^{\mathrm{b}}$ & $8.50 \pm 0.71^{\mathrm{a}}$ & $8.80 \pm 0.63^{\mathrm{a}}$ & $8.50 \pm 0.85^{\mathrm{a}}$ \\
\hline
\end{tabular}

${ }^{1)}$ All values are mean \pm SD of the three replicates.

${ }^{\mathrm{a}-\mathrm{c}}$ Means sharing different letters in the same row are significantly different $(p<0.05)$.

${ }^{2)}$ Control, semi-dried sausage without kimchi powder; T1, semi-dried sausage with $1 \%$ hot air dried kimchi powder; T2, semi-dried sausage with 2\% hot air dried kimchi powder; T3, semi-dried sausage with 3\% hot air dried kimchi powder.

${ }^{3)}$ Scores based on a 10 point scale, where $1=$ extremely undesirable and $10=$ extremely desirable for color, flavor, kimchi taste, and overall acceptability; $1=$ extremely tough and $10=$ extremely tender for tenderness; $1=$ extremely dry and $10=$ extremely juicy for juiciness. 
4. Color, flavor, and tenderness were significantly different among the different treatments due to the addition of kimchi powder $(p<0.05)$. The relative amounts of added kimchi powder (Table 2) were apparent as detectable color differences by the panelists. Kimchi powder addition caused a decrease in hardness and an increase in processing yield: both changes were detected by tenderness and juiciness indicating higher moisture content. Juiciness was quite similar in all batches. And the overall acceptability and kimchi taste scores depended on level of kimchi powder. Cho (2005) reported that the addition of freeze-dried kimchi power in breakfast sausage resulted in higher sensory scores compared with control. Previous researchers also reported that dietary fiber affects tenderness and juiciness scores because it has the ability to retain moisture and prevents meats from drying out when cooked (Pszcaola, 1991). Use of fruit purees (Leheska et al., 2006), pomegranate juice (Noveena et al., 2008), tomato peel (Calvo et al., 2007), and rice bran fiber (Choi et al., 2008) also affected the color, flavor, and taste of meat products.

\section{Thiobarbituric acid reacting substance determina- tion (TBARS)}

The effects of different concentrations of kimchi powder on the TBARS values of semi-dried sausages over 6 wk of refrigerated storage are shown in Fig. 1. There was a significant increase in the TBARS values of all semidried sausages during storage. The initial TBARS values

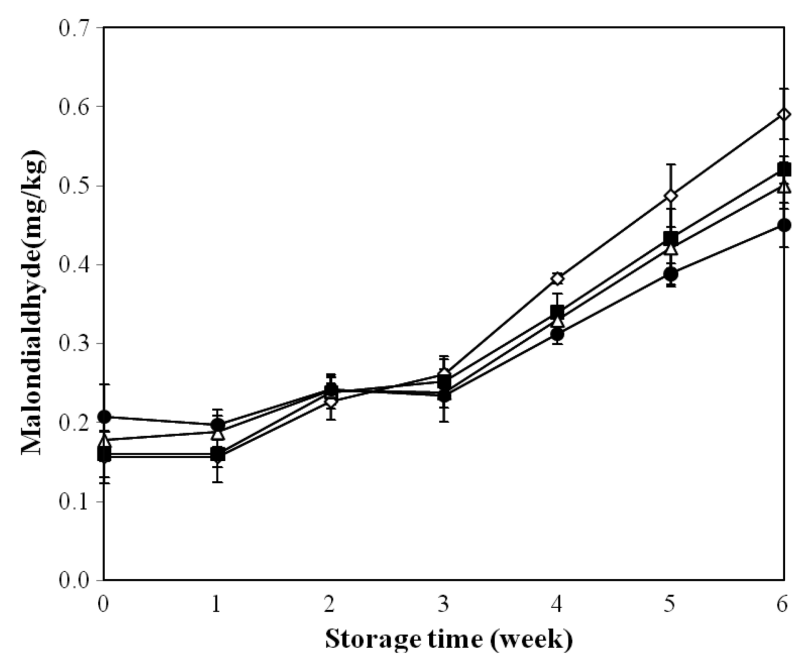

Fig. 1. Changes in TBARS value of semi-dried sausages containing various levels of kimchi powder during storage. $(\diamond)$ Control: semi-dried sausage without kimchi powder, ( $\boldsymbol{\square})$ T1: semi-dried sausage with $1 \%$ hot air dried kimchi powder, $(\triangle)$ T2: semi-dried sausage with $2 \%$ hot air dried kimchi powder, ()$^{-}$T3: semi-dried sausage with $3 \%$ hot air dried kimchi powder. were not generally different $(p<0.05)$ among the control and test sausages. However, the TBARS values of control at $3 \mathrm{wk}$, towards the end of refrigerated storage period, were higher $(p<0.05)$ than the sausages formulated with kimchi powder. The TBARS values of all sausages were considerably lower $(p<0.05)$ than control at the end of refrigerated storage indicating that kimchi powder may protect lipid oxidation in semi-dried sausages. The TBARS values indicated an increase in protection from lipid oxidation in semi-dried sausages with higher concentrations of kimchi powder. Various studies also reported that kimchi lowered TBARS values (Hwang and Song, 2000; Lee and Cheigh, 1995), and the antioxidative phenolic compounds of kimchi may contribute to the strong antioxidative activity (Cheigh and Park, 1994; Woo and Jeong, 2006). On the other hand, Lee and Kunz (2005) reported that the antioxidant effects of kimchi are not related to the amount of added kimchi. Previous research also reported that addition of mugwort powder in sausages resulted in lower TBARS values as increasing storage period compared with control (Han et al., 2006).

\section{Volatile basic nitrogen (VBN) determinations}

VBN could be used as a quality indicator for meat and fish products (Jay, 1992) and is associated with the amino acid decarboxylase activity of microorganism during storage. Fig. 2 shows the changes in VBN values during storage. VBN values of all treatment increased with increasing storage time, and control had lower VBN values than

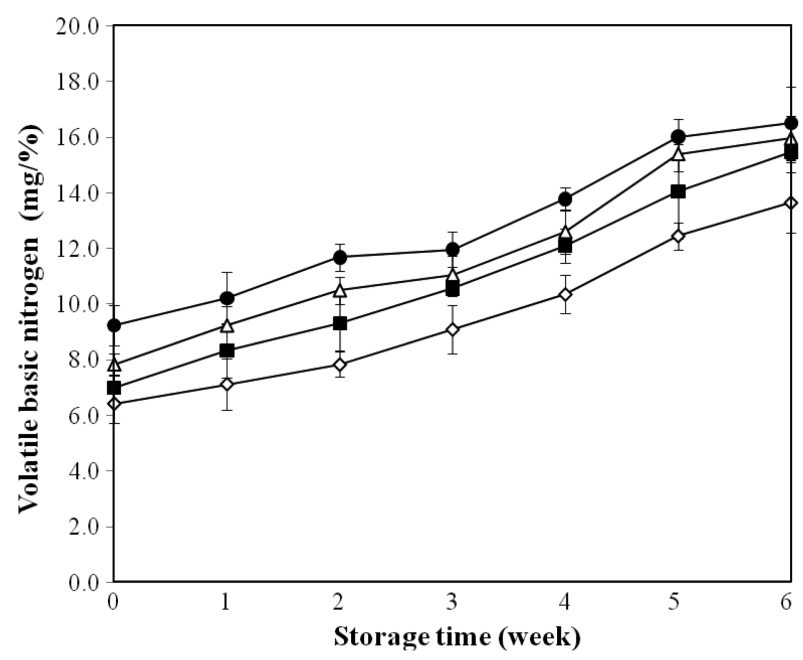

Fig. 2. Changes in VBN value of semi-dried sausages containing various levels of kimchi powder during storage. $(\diamond)$ Control: semi-dried sausage without kimchi powder, (ם) T1: semi-dried sausage with $1 \%$ hot air dried kimchi powder, $(\triangle)$ T2: semi-dried sausage with $2 \%$ hot air dried kimchi powder, (O) T3: semi-dried sausage with $3 \%$ hot air dried kimchi powder. 
other treatments all the values were less than $30 \mathrm{mg} \%$. The treatments containing kimchi powder remained at a higher VBN value. The kimchi using this study contain $1.2 \%$ of fermented shrimp and $1.2 \%$ of fermented anchovy sauce, consequently, this study reported a high range of VBN, and it could be fermented shrimps in kimchi. In fermented sea food, amino nitrogen content plays important roles as an indicator of the degree of aging or putrefaction and the optimum taste (Jay, 1992) and the VBN value of fermented shrimp was about $9.8 \mathrm{mg} \%$ (Heu et al., 2003). The observation of Kim et al. (2005) where meat containing shrimp sauce had higher VBN values compared to untreated sample and Lee et al. (1990) reported that the addition of kimchi in fermented sausages resulted in higher VBN values as increasing fermentation time, which is in agreement with the findings of the present study.

\section{Conclusion}

In summary, kimchi powder can be used as a good source of dietary fiber which is used as functional ingredient for meat products. The additions of kimchi powder influenced the physicochemical and sensory properties of semi-dried sausages and also it delayed oxidation of treatments. In terms of quality characteristics, the most desirable results were obtained for semi-dried sausages made with $2 \%$ kimchi powder. As a consequence, the meat industry could use kimchi powder as an additive to enhance the functional and technological properties of meat products.

\section{Acknowledgement}

This research was supported by the Ministry of Agriculture and Forestry (106115-02-1-SB010), Republic of Korea. The authors were also partially supported by the Brain Korean 21 (BK 21) Project from Ministry of Education and Human Resources Development.

\section{References}

1. Akoh, C. C. (1998) Fat replacers. Food Technol. 52, 47-53.

2. Aleson-Carbonell, L., Fernandez-Lopez, J., Sayas-Barbera, E., Sendra, E., and Perez-Alvarez, J. A. (2003) Utilization of lemon albedo in dry-cured sausages. J. Food Sci. 68, 18261830.

3. AOAC. (1995) Official Methods of Analysis. Of AOAC Intl. $16^{\text {th }}$ ed. Association of Official Analytical Communities, Arlington, VA, USA.
4. Ayo, J., Carballo, J., Solas, M. T., and Jumenez-Colmenero, F. (2008) Physicochemical and sensory properties of healthier frankfurters as affected by walnut and fat content. Food Chem. 107, 1547-1552.

5. Bech-Larsen, T. and Grunert, K. G. (2003) The perceived healthiness of functional foods - A conjoint study of Danish, Finnish and American consumers' perception of functional foods. Appetite 40, 9-14.

6. Byun, M. W., Lee, K. H., Kim, D. H., Kim, J. H., Yook, H. S., and Ahn, H. J. (2000) Effects of gamma radiation on sensory qualities, microbiological and chemical properties of salted and fermented squid. J. Food Protect. 63, 934-939.

7. Calvo, M. M., Garcia, M. L., and Selgas, M. D. (2007) Dry fermented sausages enriched with lycopene from tomato peel. Meat Sci. 80, 162-172.

8. Cheigh, H. S. and Park, K. Y. (1994) Biochemical, microbological, and nutritional aspects of kimchi (Korean fermented vegetable products). Crit. Rev. Food Sci. 34, 175-203.

9. Cho, Y. B. (2005) Development of breakfast sausage prepared with freeze-dried kimchi powder. Korean J. Food Culture. 20, 391-396.

10. Choi, Y. S., Choi, J. H., Han, D. J., Kim, H. Y., Lee, M. A, Lee, E. S., Jeong, J. Y., Paik, H. D., and Kim, C. J. (2008) Effects of rice bran fiber on quality of low-fat Tteokgalbi. Food Sci. Biotechnol. 17, 959-964.

11. Claus, J. R. and Hunt, M. C. (1991) Low-fat, high-added water bologna formulated with texture-modifying ingredients. J. Food Sci. 56, 643-647.

12. Cofrades, S., Guerra, M. A., Carballo, J., Fernandes-Martin, F., and Colmenero, F. J. (2000) Plasma protein and soy fiber content effect on bologna sausage properties as influenced by fat level. J. Food Sci. 65, 281-287.

13. Crehan, C. M., Hughes, E., Troy, D. J., and Buckley, D. J. (2000) Effects of fat level and maltodextrin on the functional properties of frankfurters formulated with 5, 12 and $30 \%$ fat. Meat Sci. 55, 463-469.

14. Deda, M. S., Bloukas, J. G., and Fista, G. A. (2007) Effect of tomato paste and nitrite level on processing and quality characteristics of frankfurters. Meat Sci. 76, 501-508.

15. Eim, V. S., Simal, S., Rossello, C., and Femenia, A. (2008) Effects of addition of carrot dietary fiber on the ripening process of dry fermented sausage (sobrassada). Meat Sci. 80, 173-182.

16. Fernandez-Gin, J. M., Ferbabdez-Lopez, J., Sayas-Barbera, E., and Perez-Alvarez, J. A. (2005) Meat products as functional foods: A review. J. Food Sci. 70, 37-43.

17. Garcia, M. L., Dominguez, R., Galvex, M. D., Casas, C., and Selgas, M. D. (2002) Utilization of cereal and fruit fibres in low fat dry fermented sausages. Meat Sci. 60, 227-236.

18. Grigelmo-Miguel, N., Abadias-Seros, M. I., and Martin-Belloso, O. (1999) Characterisation of low-fat high-dietary fibre frankfurters. Meat Sci. 52, 247-256.

19. Han K. H., Choi, I. S., and Lee, C. H. (2006) The physicochemical and storage characteristics of sausage added mugwort powder. Korean J. Food Sci. Ani. Resour. 26, 356-361.

20. Herrero, A. M, Ordones, J. A., Avila, M. D. R., Herranz, B., 
Hoz, L., and Combero, M. I. (2007) Breaking strength of dry fermented sausages and their correlation with texture profile analysis (TPA) and physic-chemical characteristics. Meat Sci. 77, 331-338.

21. Heu, M. S., Kim, J. S., and Shahidi, F. (2003) Components and nutritional quality of shrimp processing by-products. Food Chem. 82, 235-242.

22. Hughes, E., Cofrades, S., and Troy, D. J. (1997) Effects of fat level, oat fibers and carrageenan frankfurters formulated with 5, 12, and 30\% fat. Meat Sci. 45, 273-281.

23. Hunt, M. C., Acton, J. C., Benedict, R. C., Calkins, C. R., Cornforth, D. P., Jeremiah, L. E., Olson, D. G., Salm, C.P., Savell, J. W., and Shivas, S. D. (1991) Guidelines for meat color evaluation. In: $44^{\text {th }}$ Annual Reciprocal Meat conference: June 9-12; Manhattan, Kans. Chicago. Ill/: Natl. Livestock and Meat Board. pp. 3-17.

24. Hwang, J. W. and Song, Y. O. (2000) The effects of solvent fractions of kimchi on plasma lipid concentration of rabbit fed high cholesterol diet. J. Korean Soc. Food Sci. Nutr. 29, 204-209.

25. Jay, J. M. (1992) Indicators of food microbial quality and safety. In: Modern Food microbiology. Jay JM. New York: Chapman and Hall. pp. 413-433.

26. Jimenez-Colmenero, F. (1996) Technologies for developing low-fat meat products. Trends Food Sci. Tech. 7, 42-48.

27. Jimenez-Colmenro, F., Carballo, J., and Cofrades, S. (2001) Healthier meat and meat products: Their role as functional foods. Meat Sci. 59, 5-13.

28. Kim, J. S., Shahidi, F., and Heu, M. S. (2005) Tenderization of meat by salt-fermented sauce from shrimp processing byproducts. Food Chem. 93, 243-249.

29. Kim, M. J., Song, Y. S., and Song, Y. O. (1998) The fibrinolytic activity of kimchi and its ingredients in vivo and in vitro. J. Korean Soc. Food Sci. Nutr. 27, 633-639.

30. Kovacs, A., Zarnoczay, G., and Gasparik Reichardt, J. (2007) Development of new functional meat products. In Proceeding of the fourth international FFNet meeting on functional foods.

31. Lee, J. Y. and Kunz, B. (2005) The antioxidant properties of baechu-kimchi and freeze-dried kimchi-powder in fermented sausages. Meat Sci. 69, 741-747.

32. Lee, M. A., Han, D. J., Choi, J. H., Choi, Y. S., Kim, H. Y., Jeong, J. Y., Paik, H. D., and Kim, C. J. (2008a) Effect of hot air dried kimchi powder on the quality characteristic of lowfat sausages. Korean J. Food Sci. Ani. Resour. 28, 146-153.

33. Lee, M. A., Han, D. J., Jeong, J. Y., Choi, J. H., Choi, Y. S., Kim, H. Y., Paik, H. D., and Kim, C. J. (2008b) Effect of kimchi powder level and drying methods on quality characteristics of breakfast sausage. Meat Sci. 80, 708-714.

34. Lee, S. K., Yoo, I. J. Kim, Y. B., and Kim, K. S. (1990) Fermentation of sausage using kimchi. Korean J. Food Sci. Ani. Resour. 32, 707-714.

35. Lee, Y. O. and Cheigh, H. S. (1995) Antioxidative effect of kimchi on the lipid oxidation of cooked meat. J. Korean Soc. Food Sci. Nutr. 24, 1005-1009.
36. Leheska, J. M., Boyce, J., Brooks, J. C., Hoover, L. C., Thompson, L. D., and Miller, M. F. (2006) Sensory attributes and phenolic content of precooked pork breakfast sausage with fruit purees. J Food Sci. 71, 249-252.

37. Meilgaard, M., Civille, G. V., and Carr, B. T. (1999) Sensory evaluation techniques. $3^{\text {rd }}$ Edition. CRC Press, Inc., Boca Raton, Florida, USA. pp. 133-158.

38. Mendoza, E., Garcia, M. L., Casas, C., and Selgas, M. D. (2001) Inulin as fat substitute in low fat, dry fermented sausages, Meat Sci. 57, 387-393.

39. Morin, L. A., Temelli, F., and McMullen, L. (2004) Interactions between meat proteins and barley (Hordeum spp.) $\beta$ glucan within a reduced-fat breakfast sausage system. Meat Sci. 68, 419-430.

40. Noveena, B. M., Sen, A. R., Vaithiyanathan, S., Babji, Y., and Kondaiah, N. (2008) Comparative efficacy of pomegranate juice, pomegranate rind powder extract and BHT as antioxidants in cooked chicken patties. Meat Sci. 80, 1304-1308.

41. Park, K. Y. (1995) The nutrition evaluation, antimutagenic, and anticancer effects of kimchi. J. Korean Soc. Food Sci. Nutr. 24, 169-182.

42. Park, K. Y., Baek, K.A., Rhee, S. H., and Cheigh, H. S. (1995) Antimutagenic effects of kimchi. Food Sci. Biotechnol. 4, 141-145.

43. Pearson, D. (1968) Application of chemical methods for the assessments of beef quality. J. Sci. Food Agr. 19, 366-369.

44. Pszczola, D. (1991). Oat-bran based ingredient blend replaces fat in ground beef and pork sausage. Food Technol, 45, 60-66.

45. SAS. (1999). SAS user's guide: basic statistical analysis. Cary, N.C.: SAS Inst.

46. Sebranek, J. and Bacus, J. (2007) Natural and organic cured meat products: Regulatory, manufacturing, marketing, quality and safety issues. American meat science association, White Paper Series, number 1 March.

47. Shand, P. J. (2000) Textural, water holding, and sensory properties of low-fat pork bologna with normal or waxy starch hull-less barley. J. Food Sci. 65, 101-107.

48. Steenblock, R. L., Seeranek, J. G., Olson, D. G., and Love, J. A. (2001) The effects of oat fiber on the properties of light bologna and fat-free frankfurters. J. Food Sci. 66, 14091415.

49. Tarladgis, B. G., Watts, B. M., and Younathan, M. T. (1960) A distillation method for the quantitative determination of malonaldehyde in rancid food. J. Am. Oil Chem. Soc. 37, 4448.

50. Thebaudin, J. Y., Lefebvre, A. C., Harrington, M., and Bourgeois, C. M. (1997) Dietary fiber: Nutritional and technological interest. Trends Food Sci. Tech. 8, 41-48.

51. Woo, S. M. and Jeong, Y. J. (2006) Effect of germinated brown rice concentration on free amino acid levels and antioxidant and nitrite scavenging activity in kimchi. Food Sci. Biotechnol. 15, 351-356.

$\overline{\text { (Received 2009.6.15/Revised 2009.7.14/Accepted 2009.7.17) }}$ 